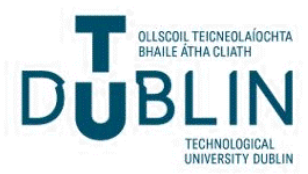

Technological University Dublin

ARROW@TU Dublin

Articles

School of Chemical and Pharmaceutical

Sciences

2011

\section{Now for the Science Bit: Implementing Community-based Learning in Chemistry}

\author{
Claire M. McDonnell \\ Technological University Dublin, claire.mcdonnell@tudublin.ie \\ Patricia Ennis \\ Technological University Dublin, patricia.ennis@tudublin.ie \\ Leslie Shoemaker \\ Technological University Dublin, Leslie.Shoemaker@tudublin.ie
}

Follow this and additional works at: https://arrow.tudublin.ie/scschcpsart

Part of the Chemistry Commons, and the Science and Mathematics Education Commons

\section{Recommended Citation}

McDonnell, C., Ennis, P., Shoemaker, L.: Now for the Science Bit: Implementing Community-based Learning in Chemistry. Education + Training, 53 (2/3), 218 - 236. 2011. doi.org/10.21427/8367-8s88

This Article is brought to you for free and open access by the School of Chemical and Pharmaceutical Sciences at ARROW@TU Dublin. It has been accepted for inclusion in Articles by an authorized administrator of ARROW@TU

Dublin. For more information, please contact

arrow.admin@tudublin.ie, aisling.coyne@tudublin.ie, gerard.connolly@tudublin.ie.

Funder: $\mathrm{CBL} / \mathrm{CBR}$ projects

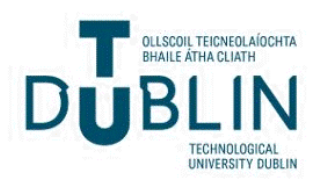




\title{
Now for the science bit: Implementing community-based learning in chemistry
}

Authors: $\quad$ Claire Mc Donnell* and Patricia Ennis, School of Chemical and Pharmaceutical Sciences, Dublin Institute of Technology, Kevin St. Dublin 8, Ireland, Leslie Shoemaker, Department of Electrical Services Engineering, Dublin Institute of Technology, Kevin St. Dublin 8, Ireland.

* claire.mcdonnell@dit.ie

\begin{abstract}
Purpose - The purpose of this paper is to contribute to the understanding of student learning from community engagement by critically assessing the implementation of this pedagogical approach in the context of teaching and learning chemistry and also evaluating the role of personal development in student-community engagement.
\end{abstract}

Design/methodology/approach - A case study on the implementation since 2007 of community-based learning (also called service-learning) projects in an academic department in Ireland is presented. Analysis of assessment grades, student reflective accounts and evaluation questionnaires informs this work as does a recently completed self-assessment of our activities using Shumer's Self-Assessment for Service Learning.

Findings - A marked improvement in student engagement and confidence and their appreciation of how their subject is applied in real-world situations is reported. Some difficulties arise however in relation to the level of critical thinking and self-awareness evident in reflective writing assignments as the students were generally not experienced in reflection on personal experiences. The extent to which it has been demonstrated that genuine community needs are being met is also an issue in some instances.

Originality/value - The paper describes some innovative practices as CBL is not wellestablished in the discipline concerned, chemistry, and it has also not often been applied to the benefit of small local businesses. A critical analysis of the process followed when CBL activities were implemented in an institution without an existing, well-established culture of applying this pedagogical approach is provided as this is a perspective not often explored in the literature.

Keywords: Community engagement, chemistry education, service-learning, selfreflection, personal development.

Article type: Case study 


\section{Introduction}

This paper presents a case study on implementation of community-based learning (CBL) projects in the School of Chemical and Pharmaceutical Sciences in Dublin Institute of Technology (DIT). Two projects were piloted in 2007. One involved students preparing suitable posters and demonstrations and interacting with secondary school students to help develop their understanding of chemistry topics and, in the other, undergraduates performed chemical risk assessments and safety audits in schools or small businesses. Both projects have been continued and the provision has extended since and there are now three CBL projects and two community-based research (CBR) projects offered by the School.

\section{Student learning from community engagement: Background in DIT and terminology} used

This paper focuses on CBL initiatives implemented to promote student learning from community engagement on undergraduate chemistry courses at Dublin Institute of Technology (DIT). Some CBR initiatives will also be discussed but they are not examined in the same detail. To ensure clarity, the interpretations of the terms employed to classify the learning and teaching activities reported in this paper are now provided. The original definition of "community-based learning" adopted in 2006, when these projects were developed, was taken from Bringle and Hatcher (1996, p. 122);

a credit-bearing educational experience in which students participate in an organised service activity that meets identified community needs and reflect on the service activity in such a way as to gain further understanding of the course content, a broader appreciation of the discipline and an enhanced sense of civic responsibility.

Bringle and Hatcher were actually defining "service-learning" in this case and this is a term that originated in the United States. There has been some debate over the most appropriate words to use to categorise student-community engagement in Ireland. Boland and McIlrath (2007) discuss the localisation process involved in more detail and, as an interim measure, have proposed using "pedagogies for civic engagement" to label practices that involve student-community engagement. A similar deliberation occurred locally in DIT. In 2001, some academic staff in the Faculty of Tourism and Food were the first to implement this approach and they initially used the term "service-learning" (Kerins, 2010). By 2005, DIT was successful in obtaining funding for three years to extend these practices across all 
disciplines (Ahern, 2005) and, at this point, the initiative was named the Community Learning Programme (CLP). The successor to this project has been funded for another three years and was launched in September 2008. It was renamed the programme for Students Learning With Communities (SLWC). This change of title has been found by the authors to facilitate a more ready recognition by prospective community partners of what is involved. One of the aims of the SLWC programme remains the initiation of effective community engagement across DIT but development and consolidation of existing projects and national and international collaboration are also important objectives reflecting that the project has become more established and embedded (Cooke, 2009).

Currently, the authors use the terms CBL (community-based learning) and CBR (communitybased research) to describe the learning and teaching strategies used but we clearly identify to all partners - students, fellow staff and community partners- that these activities are part of the SLWC programme in DIT. It may seem that unnecessary detail is being provided in relation to labels and terms but it is often the case that misunderstandings arise due to confusion between the type of projects described here and volunteering activities or student work placements. Bringle and Hatcher (1996, p. 226) have observed that "creating a common understanding of what constitutes service learning at a particular institution will pay dividends later." In this regard, an institutional level definition is now provided by SLWC which incorporates CBL and CBR [I];

Students Learning With Communities involves DIT staff and/or students working with community partners (local groups, not-for-profit organisations, etc.) to develop reallife projects. Learning comes alive for the students as they work on these projects with real clients, applying their specialist subject skills, and receiving course credits for their work. The community becomes part of the teaching process and benefits from the students' work. These projects give all participants the opportunity to engage in critical thinking and to develop their social awareness. The Programme for Students Learning With Communities ultimately aims to energise participants to work for social change.

\section{Students learning with communities / community-based learning in chemistry}

When the first two CBL projects were piloted in the School of Chemical and Pharmaceutical Sciences at DIT in the academic year 2006/7, not much information on similar initiatives in 
chemistry in Europe was available. The authors were aware of a Chemistry Science Shop at the University of Groningen (Mulder, 2008) but the projects there essentially involved CBR which was not our initial focus. Some service-learning projects were reported in the United States (Kesner and Eyring, 1999; Wiegand and Strait, 2000; Hatcher-Skeers and Aragon, 2002; Draper, 2004; Esson et al., 2005; Middlecamp et al., 2006) however.

The expected advantages of implementing CBL projects were that students would see how their discipline knowledge is applied in practice and that staff and students would be involved in working with the community as a core element of their work and studies instead of having to find extra time for these activities (Esson et al., 2005). Hatcher-Skeers and Aragon (2002) observe that service-learning provides an excellent means of achieving active learning. Active learning and a focus on what the student, not the teacher, is doing are central elements of teaching that leads to good quality learning (Biggs, 1999).

\section{Initial implementation}

As CBL was already in place in the DIT Faculty of Tourism and Food, this made it easier on an institutional level to introduce it elsewhere. The approach taken in developing pilot projects recommended by the CLP staff was to review all modules already in place to determine whether they could be modified so that one of the learning and teaching activities could be applied to the benefit of the community and also to find out if there were any existing CBL projects which had not had the term applied to them. In this case, we identified two suitable activities that required some modification. One difference between the implementation of these projects and those previously introduced in the Faculty of Tourism and Food was that, in our case, they were not elective and all students in a particular group were required to take the modules that included CBL activities. This decision was based on resource and operational considerations. However, the CBR projects introduced since then are options available to be selected by final year undergraduate project students. Another difference was that we introduced components of modules (either $40 \%$ or $60 \%$ ) instead of entire modules involving CBL. This was for pragmatic reasons relating to the learning hours available and the existing curriculum. Table 1 summarises details of these module components, including associated learning outcomes and assessments. 
This method that we used initially provided a means to implement modules with a strong $\mathrm{CBL}$ emphasis quickly and thus was the preferred approach during the pilot phase. This approach did not strictly follow the recommended model of first formally asking potential community partners to identify their requirements at both an institutional and course level (Bringle and Hatcher, 1996). In the case of the Year 2 project described in Table 1 which has been labelled Activity $A$, it had already been established informally that the community partners (teachers and students in local secondary schools) had an existing need which could be met by suitably designed teaching and learning activities. For the Year 4 project labelled Activity B described in Table 1 however, the existence of a genuine community need has not been as clearly established.

Table 1: $\quad$ Summary of Community-Based Learning (CBL) Pilot Projects Initiated in Academic Year 2006/7

\begin{tabular}{|c|c|c|}
\hline & Activity A & Activity B \\
\hline $\begin{array}{l}\text { Year, Course and } \\
\text { Module Title }\end{array}$ & $\begin{array}{l}\text { Year 2, B.Sc. Medicinal Chemistry } \\
\text { and Pharmaceutical Sciences - } \\
\text { Professional Skills module. }\end{array}$ & $\begin{array}{l}\text { Year 4, B.Sc. Forensic and } \\
\text { Environmental Analysis - Chemical } \\
\text { Control, Radioactivity and } \\
\text { Bioinorganic Chemistry module. }\end{array}$ \\
\hline Learning Aims & $\begin{array}{l}\text { To develop information literacy, } \\
\text { communication and teamwork } \\
\text { skills. }\end{array}$ & $\begin{array}{l}\text { To acquaint the student with } \\
\text { requirements of the legislation on } \\
\text { to the use of chemicals in the } \\
\text { workplace and how compliance is } \\
\text { achieved and to develop } \\
\text { teamwork and organisational } \\
\text { skills. }\end{array}$ \\
\hline $\begin{array}{l}\text { Learning } \\
\text { Objectives }\end{array}$ & $\begin{array}{l}\text { 1) Design and plan a scientific } \\
\text { poster presentation and/or } \\
\text { demonstration to communicate an } \\
\text { understanding of the application of } \\
\text { chemistry in everyday life to } \\
\text { second level students. } \\
\text { 2) Find and retrieve information for } \\
\text { the poster/demonstration. } \\
\text { 3) Present the posters and/or } \\
\text { perform demonstrations during an } \\
\text { outreach event and reflect on the } \\
\text { assignment. }\end{array}$ & $\begin{array}{l}\text { 1) Appreciate the requirements of } \\
\text { the health and safety legislation in } \\
\text { relation to the work environment. } \\
\text { 2) Have a working knowledge of } \\
\text { the specific legislation pertaining } \\
\text { to the 'use' of chemicals in the } \\
\text { work place. } \\
\text { 3) Undertake a chemical risk } \\
\text { assessment and use chemicals } \\
\text { safely in the workplace. } \\
\text { 4) Develop group work and } \\
\text { organisational skills. }\end{array}$ \\
\hline $\begin{array}{l}\text { Additional } \\
\text { Information }\end{array}$ & $\begin{array}{l}\text { Students assigned to groups of } 2-3 \text {, } \\
\text { online discussion boards used for } \\
\text { progress reports and queries. }\end{array}$ & $\begin{array}{l}\text { Students work in groups of 3-4 } \\
\text { and select their groups } \\
\text { themselves. They perform } \\
\text { chemical risk assessments and }\end{array}$ \\
\hline
\end{tabular}




\begin{tabular}{|c|c|c|}
\hline & & $\begin{array}{l}\text { safety audits in schools or small } \\
\text { businesses. }\end{array}$ \\
\hline $\begin{array}{l}\text { Assessment } \\
\text { Components }\end{array}$ & $\begin{array}{l}\text { Presentation and/or } \\
\text { demonstration (group). } \\
\text { Contribution during lab sessions } \\
\text { and to discussion board. } \\
\text { Project diary. } \\
\text { Reflective writing assignment. }\end{array}$ & $\begin{array}{l}\text { Project plan (group). } \\
\text { Presentation (group). } \\
\text { Report (group). } \\
\text { Reflective writing assignment. }\end{array}$ \\
\hline $\begin{array}{l}\text { Weighting of CBL } \\
\text { Project in } \\
\text { Module }\end{array}$ & ( & $60 \%$ \\
\hline $\begin{array}{l}\text { Student Learning } \\
\text { Hours }\end{array}$ & $\begin{array}{l}15 \text { to } 18 \text { contact hours and } 20 \\
\text { hours independent study }\end{array}$ & $\begin{array}{l}8 \text { contact hours and } 40 \text { hours } \\
\text { independent study }\end{array}$ \\
\hline $\begin{array}{l}\text { Number of } \\
\text { Students }\end{array}$ & 45 over 4 academic years & 103 over 4 academic years \\
\hline
\end{tabular}

\subsection{Additional details on year 2 community-based learning project (Activity A)}

This CBL activity was based on an existing one that required students to prepare posters and demonstrate experiments that had been set up by academic staff to secondary school students during Science Week at DIT which takes place each November. The main modification was the requirement that students develop a suitable demonstration themselves and the inclusion of a reflective writing assignment as well as allocation of some additional teaching contact hours. In the first year of implementation, semesterisation was introduced at DIT and the module was rescheduled to take place in Semester 2 (January to May) which meant that the timing did not coincide with Science Week. The alternative outreach event selected was the Royal Society of Chemistry (RSC) Chemistry at Work day which took place in March 2007 (Royal Society of Chemistry, 2010). This was the first year that DIT hosted the event and it was a tremendous benefit to have the students helping with the organisation. They were assigned in groups of two to assist a presenter from industry or a public service organisation (e.g. cosmetics, food, adhesives, medical device and pharmaceutical companies and environmental and forensic laboratories) and prepared posters and demonstrations related to the main themes the presenter was introducing [II].

The same approach was taken in 2008 but, in 2009, there were staff resource issues which meant that DIT was not able to host the Chemistry at Work event. In order to organise an alternative, Mr Joe Nicholl, a chemistry teacher in a local secondary school, Synge St. Christian Brothers School (CBS), was contacted. Following a meeting at which the principles of the DIT SLWC programme were explained to him and possible useful interactions 
between his students and those at DIT were discussed, a CBL project was initiated which resembled the original outline developed but allowed for more sustained contact with these secondary school students. This was achieved by making a Google Groups ${ }^{\mathrm{TM}}$ online discussion board available for five weeks. Discussion threads were provided for each of three topics from the senior cycle (Leaving Certificate) syllabus which had been agreed in advance with their teacher and students were invited to post any questions they had. DIT students then carried out some research and submitted an answer to their lecturer who gave feedback before it was posted back on the discussion board. This approach avoided posting of unchecked information but did delay the process somewhat. In the final week, the students from Synge St. CBS visited DIT and instruments described in their textbooks which most secondary schools do not have (a mass spectrometer and a gas chromatography system) were demonstrated to them and the underlying principles and their applications to research in DIT were discussed and summarised in scientific posters by the third level students [III]. This project was repeated this year but, in order to improve the interaction, the DIT students also visited the school during a chemistry practical lesson and worked alongside the students there.

\subsection{Additional details on year 4 community-based learning project (Activity B)}

This CBL activity was based on replacing an assessment that involved asking learners to undertake chemical risk assessments for a case study with a group assignment to perform chemical risk assessments and safety audits in secondary school laboratories. In the first year it was piloted, it was found that it was quite difficult to find times that suited both the schools and the students during which they could perform the audits. In addition, the authors spent a considerable amount of time in advance of the module contacting schools that were less than an hour's journey by public transport from DIT to see if they were willing to accommodate a safety audit.

In order to make the project sustainable, it was decided to modify it the following year so that learners themselves made the contact to request that they be allowed to perform a safety audit and risk assessment and, as the number of schools were limited, they could approach any small to medium enterprise (SME) with up to 50 employees or non-profit organisation. This change was very successful in reducing the advance work required of staff and made the students more involved in the process and, hence, more engaged. An initiative in Canada in which service-learning was applied to the benefit of a small local business has recently been 
reported in the literature (Simola, 2009). In 2010, this activity was successfully extended to a similar module on another course in the School of Chemical and Pharmaceutical Sciences. This has helped consolidate the position of community-based learning as a pedagogical approach in our department and has demonstrated that the sustainability measures made in this case were effective.

\subsection{Additional community-based learning activity implemented (Activity C)}

A third CBL activity, labelled Activity C, was introduced to a Professional Skills module in Year 2 of our Forensic and Environmental Analysis course in 2008/9. It was an extension of a similar activity that had been operational in the DIT Faculty of Engineering for several years (Shoemaker, 2006). Some minor modifications were made to the assessment criteria and weightings and a Staff and Student Handbook was prepared. One academic staff member accompanied each group of students to a school to give their presentation on Studying Science and College Life and this involvement was undertaken on a voluntary basis. This arrangement is sustainable as it only requires each lecturer to do so once every two years and staff recognise the usefulness of an activity that promotes the study of science at third level. Table 2 below summarises details of this project, labelled Activity $\mathrm{C}$, including associated learning outcomes and assessments.

Table 2: $\quad$ Summary of the Additional Community-Based Learning (CBL) Project Initiated in 2008/9, Activity C.

\begin{tabular}{|l|l|}
\hline $\begin{array}{l}\text { Year, Course and } \\
\text { Module Title }\end{array}$ & $\begin{array}{l}\text { Year 2, B.Sc. Forensic and Environmental Analysis - Professional } \\
\text { Development module }\end{array}$ \\
\hline Learning Aims & $\begin{array}{l}\text { To develop group work, organisational, research, presentation, } \\
\text { problem solving, communication (verbal, non-verbal and } \\
\text { written) and information and communication technology skills. }\end{array}$ \\
\hline Learning Objectives & $\begin{array}{l}\text { 1) Prepare a PowerPoint } \\
\text { College Life for second level students. } \\
\text { 2) Find and retrieve information for the presentation. } \\
\text { 3) Send a confirmation letter to the assigned school. } \\
\text { 4) Present in the school. } \\
\text { 5) Summarise data from the evaluation forms collected. } \\
\text { 6) Reflect on the assignment. }\end{array}$ \\
\hline Additional Information & $\begin{array}{l}\text { Students assigned to groups of 3. One academic staff member } \\
\text { attends school with each group. }\end{array}$ \\
\hline Assessment \\
Components & $\begin{array}{l}\text { Confirmation letter to school . } \\
\text { Professional behaviour. } \\
\text { Presentation content (submitted in advance). } \\
\text { Presentation content and delivery (in school). }\end{array}$ \\
\hline
\end{tabular}




\begin{tabular}{|l|l|}
\hline & $\begin{array}{l}\text { Summary of results from evaluation forms from audience. } \\
\text { Reflective essay. }\end{array}$ \\
\hline $\begin{array}{l}\text { Weighting of CBL } \\
\text { Project in Module }\end{array}$ & $50 \%$ \\
\hline Student Learning Hours & 15 contact hours and 35 hours independent study \\
\hline Number of Students & 51 over 2 academic years \\
\hline
\end{tabular}

\subsection{Introduction of Community-Based Research (CBR) projects}

Both CBR projects that are now available to final year project students in our School to select arose as a result of the efforts of the staff in the CLP and its successor, the SLWC programme. The projects are part of two larger cross-disciplinary ventures now coordinated by the SLWC staff; College Awareness of Road Safety (CARS) [IV] and the LIFELINE [V] and Community Garden project (Wynne-Jones, 2009). Some details are provided in Table 3 below. These initiatives have been invaluable in providing a means of becoming involved in multifaceted, long term projects and it is perhaps a measure of the extent to which community engagement has been developed at DIT that this level of cooperation and interaction has now been achieved.

Table 3: $\quad$ Summary of the Community-Based Research Projects Developed

\begin{tabular}{|c|c|c|}
\hline $\begin{array}{l}\text { Name of Cross- } \\
\text { Disciplinary } \\
\text { Project }\end{array}$ & $\begin{array}{l}\text { College Awareness of Road Safety } \\
\text { (CARS) }\end{array}$ & $\begin{array}{l}\text { LIFELINE and Community Garden } \\
\text { urban renewal projects }\end{array}$ \\
\hline Year Initiated & 2008 & 2010 \\
\hline $\begin{array}{l}\text { Nature of CBR } \\
\text { Project }\end{array}$ & $\begin{array}{l}\text { Breath and urine alcohol analysis } \\
\text { on student volunteers the } \\
\text { morning after they have been } \\
\text { drinking alcohol. }\end{array}$ & $\begin{array}{l}\text { Long-term study of soil quality at } \\
\text { proposed site for new DIT campus } \\
\text { in Grangegorman and in community } \\
\text { gardens. }\end{array}$ \\
\hline $\begin{array}{l}\text { Community } \\
\text { Partners }\end{array}$ & Garda Road Safety Unit & Local resident (Kaethe Burt O’Dea) \\
\hline $\begin{array}{l}\text { Assessment } \\
\text { Components }\end{array}$ & $\begin{array}{l}\text { Project plan. } \\
\text { Lab notebook. } \\
\text { Dissertation. } \\
\text { Scientific poster presentation. }\end{array}$ & $\begin{array}{l}\text { Project plan. } \\
\text { Lab notebook. } \\
\text { Dissertation. } \\
\text { Scientific poster presentation. }\end{array}$ \\
\hline $\begin{array}{l}\text { Student Learning } \\
\text { Hours }\end{array}$ & $\begin{array}{l}120 \text { laboratory / research hours } \\
\text { and } 80 \text { hours independent study }\end{array}$ & $\begin{array}{l}120 \text { laboratory / research hours and } \\
80 \text { hours independent study }\end{array}$ \\
\hline $\begin{array}{l}\text { Number of } \\
\text { students } \\
\text { involved }\end{array}$ & 3 & 2 \\
\hline
\end{tabular}




\section{Critical assessment of the implementation of community-based learning activities}

Several components have been analysed; assessment grades, student reflective accounts and evaluation questionnaires and a self-assessment, and each will be dealt with in turn. In addition, implications of the main outcomes for the adoption of CBL by other institutions are discussed as are potential obstacles to implementing a CBL approach to chemistry. The CBR initiatives developed were not included in this evaluation. One reason is because the sample size is very small and another is that a suitable assessment mechanism that requires reflective analysis from these undergraduate research students has not yet been implemented. Therefore, a means by which a minor component of their current project assessment can be modified to allow this will be introduced as soon as possible.

\subsection{Student assessment grades for community-based learning activities}

A review of the grades obtained by students engaged in the three CBL activities offered provides a useful gauge of the learning and the level of engagement that occurred. This is quite a crude method however and the conclusions arrived at can be supported by data from other sources also. Information on grades for up to 4 academic years is presented in Table 4. To facilitate discussion of the results, the labels Activity A, B and C have been applied. For both original CBL module components introduced, pass rates of $100 \%$ have been achieved. This is taken to indicate that all students met the minimum standard in relation to the learning outcomes and that they were all sufficiently engaged and motivated to do so. The nature of the assessment in this case (see Table 1) is quite different to traditional closed book exams or essays and was planned in accordance with the principles of curriculum alignment. The basic tenet of this approach is that;

the components in the teaching system, especially the teaching methods used and the assessment tasks, are aligned with the learning activities assumed in the intended outcomes. The learner is in a sense 'trapped', and finds it difficult to escape without learning what he or she is intended to learn. (Biggs, 2005, p.2)

Therefore, if our intended alignment was achieved, learners should not have been able to easily avoid meeting the specified learning outcomes and engaging as active participants.

Table 4: Analysis of Student Grades for Community-Based Learning Module Components

\begin{tabular}{|l|l|l|l|}
\hline & Activity A & Activity B & Activity C \\
\hline
\end{tabular}




\begin{tabular}{|c|c|c|c|}
\hline & $\begin{array}{l}\text { Year 2, B.Sc. } \\
\text { Medicinal } \\
\text { Chemistry and } \\
\text { Pharmaceutical } \\
\text { Sciences }\end{array}$ & $\begin{array}{l}\text { Year 4, B.Sc. } \\
\text { Forensic and } \\
\text { Environmental } \\
\text { Analysis }\end{array}$ & $\begin{array}{l}\text { Year 2, B.Sc. } \\
\text { Forensic and } \\
\text { Environmental } \\
\text { Analysis }\end{array}$ \\
\hline $\begin{array}{l}\text { Average grade and } \\
\text { standard deviation } \\
\text { in 2006-7 }\end{array}$ & $\begin{array}{l}65.7 \pm 8.3 \\
\text { (range from } 45 \text { to } \\
78)\end{array}$ & Data not available & $\begin{array}{l}\text { CBL activity not } \\
\text { offered }\end{array}$ \\
\hline $\begin{array}{l}\text { Average grade and } \\
\text { standard deviation } \\
\text { in } 2007-8\end{array}$ & $\begin{array}{l}70.4 \pm 7.1 \\
\text { (range from } 57 \text { to } \\
75 \text { ) }\end{array}$ & $\begin{array}{l}73.4 \pm 4.2 \\
(76.6 \pm 3.7 \text { overall } \\
\text { for module })\end{array}$ & $\begin{array}{l}\text { CBL activity not } \\
\text { offered }\end{array}$ \\
\hline $\begin{array}{l}\text { Average grade and } \\
\text { standard deviation } \\
\text { in 2008-9 }\end{array}$ & $\begin{array}{l}63.1 \pm 11.6 \\
\text { (range from } 40 \text { to } \\
78 \text { ) }\end{array}$ & $\begin{array}{l}68.5 \pm 3.5 \\
(75.3 \pm 3.4 \text { overall } \\
\text { for module })\end{array}$ & $\begin{array}{l}77.3 \pm 5.2 \\
\text { (range from } 71 \text { to } \\
89 \text { ) }\end{array}$ \\
\hline $\begin{array}{l}\text { Average grade and } \\
\text { standard deviation } \\
\text { in 2009-10 }\end{array}$ & $\begin{array}{l}70.9 \pm 10.6 \text { (range } \\
\text { from } 41 \text { to } 78 \text { ) }\end{array}$ & $\begin{array}{l}74.2 \pm 5.3 \\
(77.0 \pm 4.1 \text { overall } \\
\text { for module })\end{array}$ & $\begin{array}{l}70.7 \pm 22.0 \\
\text { (range from } 0 \text { to } 86 \text { ) }\end{array}$ \\
\hline Pass rate & $100 \%$ & $100 \%$ & $96 \%$ \\
\hline
\end{tabular}

Two students failed Activity C in 2009-10. This was an unexpected and worrying outcome but this situation was an unusual one as both students did not engage with the module or with many other elements of their course over that semester. There were some repercussions in that one school visit could not go ahead as a result but the authors are going to introduce a more structured system of deadlines for each step involved in the project so that they are aware of any similar issues in sufficient time to try to overcome them.

The average grade and standard deviation for each year is also recorded in Table 4. In the case of Activity A, apart from the fact that no one failed, the range and standard deviation is comparable to most other modules the students took. Students who did not attain good grades generally did not submit all individual assessment components or made a very cursory attempt at them. The average marks for Activity B were compared to those for other modules taken in the same semester and were found to be between 5 and $10 \%$ higher. Also, the standard deviation of 3.5 to $5.3 \%$ is relatively low. For comparison, the overall module marks 
associated with Activity B are also shown. The CBL activity grade is actually somewhat lower than the overall mark in each case. Activity B has a weighting of $60 \%$ and the other $40 \%$ component of the module also involves continuous assessment whereas all other modules that semester have a weighting of $80 \%$ for examinations. The module that Activity $\mathrm{B}$ is part of also showed a higher average mark and lower standard deviation before Activity $\mathrm{B}$ was introduced and therefore this phenomenon is attributed to a combination of the subject area of this module (Professional Skills) and the continuous assessment methods employed.

\subsection{Student reflective accounts}

An element of added value that results from using a CBL approach is that, because student reflection is an integral part, this provides a rich source of data that can be used to evaluate these teaching and learning activities. It can be seen from Tables 1 and 2 that all CBL activities involved students preparing an individual reflective piece as part of the assessment. When they begin the project, the students are given guidelines that list the questions they should consider to encourage them to keep them in mind throughout. In order to promote honest and open responses, the guidelines for these reflections emphasise that the important consideration is not the opinions that are given but that all questions raised are dealt with and are discussed in sufficient depth.

A selection of excerpts from the student reflections is provided to illustrate the main themes identified.

\section{(i) "Induction" period.}

Many students recorded that they were a bit overwhelmed initially when presented with this type of project;

"The project seemed more difficult than it was - it actually ended up being a very enjoyable experience."

"When I first began, I was not too enthusiastic about the project but I found myself becoming more interested as the weeks progressed."

"I was very worried about speaking in public but, with the encouragement of the other group members, the presentation on the day did not seem as bad as I thought it would be. Public speaking is an important factor in our future careers and the more practice that we get, the more confident we will become." 
Thus, it is important that academic staff communicate what is involved as well as the underlying rationale clearly and that they provide the necessary learner support and motivation that will be required in the initial induction phase.

\section{(ii) Active learning and application of knowledge in authentic situations.}

Another common theme was that students valued the opportunity to apply what they learned in a real world context as well as participating in active learning;

"I felt that, other than our work placement, this was one of the few times that I have used my chemical knowledge in a very practical sense"

"I personally learn by action and participating. Therefore I found this assignment of great benefit as I could relate theory to practice and fully understand it."

\section{(iii) Development and appreciation of key skills.}

Learners acknowledged that the learning outcomes in relation to development of a number of key skills (teamwork, information literacy and communication skills) had been met and in many cases showed an improved understanding of their significance in a professional context;

"I gained experience in talking in front of people and helping to keep things running smoothly"

"I learned how to deal with potential work colleagues and bosses"

"Working with the students was a very good learning experience. It taught me to present information in a more hands-on way"

"I had to compromise with my group to avoid conflicts."

Thompson et al. (2005) report similar findings and have shown that students who engaged in engineering service-learning group projects at Purdue University recognised that they had developed valuable teamwork and interpersonal skills as a result.

The benefit of reflective writing in this regard was also acknowledged;

"Writing a reflective piece really helped my learning for this module because it shows me just how much I've accomplished."

\section{(iv) Appreciation of the role of a professional chemist.}

Because of the "real world" nature of a CBL project, students observed that they had developed their awareness of how chemistry is applied and related career prospects.

"Seeing the many \& varied uses of chemistry really opened my eyes." 
"I looked at the projects from the other groups and was impressed by the broad spectrum of jobs available to a chemist."

In addition, when learners worked on projects that involved interacting with professional scientists, on several occasions, they remarked on how approachable they found them to be and how much they enjoyed this aspect. Student confidence grew as a result and it also seemed that they began to identify themselves as developing professional scientists and to have a clearer idea of what that involved. Similarly, a qualitative investigation of the EPICS engineering service-learning programme at Purdue University by Thompson et al. (2005), showed that these students gained a more accurate view of what engineers really do and gained a broader view of engineering.

\section{(v) Improvement in student engagement and confidence.}

Once the initial apprehensions had been overcome, learners became enthusiastic and motivated in relation to their projects and they also noted that their confidence improved;

"I loved it because it helped me develop confidence when speaking to people I don't know"

"It (CBL) was a different type of teaching and was more interesting"

"It was very enjoyable working with my group and the project was fun to do"

"I liked the teaching experience and would like to take part in another CBL project again."

It is expected that these factors would result in an improvement in student retention although no direct evidence for this is presented.

\section{(vi) Time required and group work issues}

The most frequent difficulty that students reported was in relation to working with other members of their group. In the majority of cases however, they recognised that they could use the experience to learn more about their own role in the group and their interaction with others;

"I learned that friends don't always make the best team-mates."

About one third of the Year 4 students raised the time involved as a factor that caused problems;

"Community based learning is too time-consuming." 
This issue was examined objectively by the authors and they responded to the students that they recognise that final year students have to deal with significant workloads but that the average learning hours required for the activity are appropriate and not excessive.

\subsection{Evaluation questionnaires (from students, staff and community partners)}

The evaluation questionnaires have evolved somewhat since 2007 and, in 2010, pre and post evaluation sheets prepared by the SLWC staff were used for the first time. Much of the feedback in the evaluation questionnaires supports the themes already identified in the reflective statements. Therefore, only additional findings to these are reported here and the relevant responses are summarised in Table 5.

Table 5: $\quad$ Responses from student evaluation forms

\begin{tabular}{|l|l|}
\hline $\begin{array}{l}\text { Was the CBL assignment a suitable method for } \\
\text { assessing the associated module learning outcomes? }\end{array}$ & $100 \%$ replied yes \\
\hline $\begin{array}{l}\text { Was sufficient information provided to allow the } \\
\text { assignment to be completed effectively? }\end{array}$ & $100 \%$ replied yes \\
\hline $\begin{array}{l}\text { Which do you think would provide a better learning } \\
\text { experience, the CBL assignment or a hypothetical case } \\
\text { study? }\end{array}$ & $\begin{array}{l}\text { 96\% replied yes and 4\% replied } \\
\text { both case study and CBL } \\
\text { assignment (felt case study would } \\
\text { be good preparation) }\end{array}$ \\
\hline $\begin{array}{l}\text { Would you recommend that a similar type of CBL } \\
\text { assignment be used on this module next year? }\end{array}$ & $\begin{array}{l}\text { 96\% replied yes and 4\% replied } \\
\text { no (felt it was too much work) }\end{array}$ \\
\hline $\begin{array}{l}\text { Would you recommend that the School try to expand } \\
\text { the extent to which CBL assignments are used? }\end{array}$ & $\begin{array}{l}100 \% \text { replied yes (1 suggestion to } \\
\text { have 1 CBL activity per year) }\end{array}$ \\
\hline $\begin{array}{l}\text { Do you think the community partner(s) benefited from } \\
\text { the work you did? }\end{array}$ & \begin{tabular}{l}
$100 \%$ replied yes \\
\hline
\end{tabular}
\end{tabular}

The fact that the students thought that the assignment was an appropriate assessment of the stated learning outcomes and that they expressed a preference for CBL over a case study shows that they perceived that effective learning had occurred and that this pedagogical approach engaged the students.

Feedback was also sought from other staff and from community partners - formally by means of evaluation forms, and informally in conversation. Staff commented on the motivational aspect to these projects that arises from the responsibility students are given and the authentic context. They were generally impressed by the commitment and effort shown by students and 
observed that working with them towards a common goal was a positive experience. This opinion is supported by feedback from students;

"On the day, there was a great interaction with the chemistry lecturers."

Evaluations from community partners for Activities A and C (teachers and students) have been positive. Feedback has been more difficult to obtain in the case of activity B however and the authors intend to modify the SLWC community partner evaluation form and implement it in 2010-2011.

\subsection{Self-Assessment}

At the end of 2009, a self-assessment was performed on the student-community engagement activities in our School using Shumer's Self Assessment for Service-Learning (Shumer, 2000). The process involves identifying the strengths and weaknesses of a service-learning initiative and prioritising two action steps to improve it. This action plan is then reviewed on a regular basis. The results of the self assessment are summarised in Table 6 .

Table 6: Results from the self-assessment (Shumer, 2000) performed on student-community engagement activities

\begin{tabular}{|l|l|}
\hline Strengths identified & Action priorities \\
\hline $\begin{array}{l}\text { We consider SLWC (Students Learning With } \\
\text { Communities) activities important in improving } \\
\text { teaching and learning }\end{array}$ & $\begin{array}{l}\text { Provision of structured student } \\
\text { reflection that encourages critical } \\
\text { thinking }\end{array}$ \\
\hline $\begin{array}{l}\text { The purposes of our SLWC programme are clear } \\
\text { to everyone involved }\end{array}$ & $\begin{array}{l}\text { Ensuring that the SLWC activities are } \\
\text { meeting genuine community needs }\end{array}$ \\
\hline $\begin{array}{l}\text { The purpose of our initiative is clearly linked to } \\
\text { meaningful activities and learning objectives }\end{array}$ & \\
\hline
\end{tabular}

Two of our strengths reflect the success of SLWC in effectively developing and raising awareness of CBL and CBR at DIT ("We consider SLWC activities important in improving teaching and learning" and "The purposes of our SLWC programme are clear to everyone involved") while another relates to the curriculum alignment approach used ("The purpose of our initiative is clearly linked to meaningful activities and learning objectives"). The action priorities deal with weaknesses in two areas; encouraging meaningful student reflection and meeting genuine community needs and they will now be discussed in further detail.

\section{(i) Developing reflection that encourages critical thinking}


The effectiveness of the reflection that occurs has been a concern to the authors since CBL activities were first introduced in the School as it is recognised as a central feature of any such initiative (Bringle and Hatcher, 1997). It has been found that some learners have produced reflective pieces that show that they have thoroughly considered their personal and professional development and the impact on their learning while others perform a less satisfactory analysis with very little critical thinking. In addition, social development and active citizenship were not explicitly mentioned in the reflective guidelines until 2010 and therefore were not usually considered by students.

One issue that has arisen is that, unlike some other disciplines, chemistry undergraduates have not usually been asked to reflect on their feelings, attitudes and personal experiences before - and their lecturers also often do not have much experience of guiding students through this type of reflective process. Because of this, the authors initially felt it necessary to be quite prescriptive in the guidelines for reflection provided. However, at this point, they are confident enough to explore developing this element to improve the level of critical thinking and to incorporate further reflection on active citizenship. It is also proposed that a reflective writing task can be incorporated into the first year to provide an introduction to this approach then. The SLWC staff are very supportive in this regard and provide training for academic staff and relevant resources on their website.

\section{(ii) Meeting genuine needs in the community}

This area for improvement is closely linked to the previous one as one important facet is that the learner be prompted to reflect on their social awareness. The authors are of the opinion that a genuine community need exists in the case of all three CBL activities undertaken but the extent to which that has already been explored varies. Activities $\mathrm{A}$ and $\mathrm{C}$ respond to a need expressed by the teachers in the schools concerned but it is intended to document this more explicitly and keep informed of any changes by asking them to complete a community partner pre- and post-project evaluation form developed by the SLWC staff which will capture their feedback on future interactions and improvements that could be undertaken. Santas (2009) describes how reciprocity has been incorporated into biology service-learning. This approach ensures that feedback from the community partner is ongoing and, in this way, an effective project results that maximises its potential. Activity B involves the students themselves finding a community partner. It has been established that this activity has proven successful in ensuring that the students gain the discipline knowledge and experience that 
they should but more consideration will need to be given to ensuring that each community partner is consulted with sufficiently to be able to make the activity as worthwhile as possible to them.

\subsection{Evaluating the role of personal development in student-community engagement}

Most of the issues that relate to student personal development that occurred as a result of $\mathrm{CBL}$ activities have already been discussed but they will now be drawn together. The main source of evidence of personal development is the reflective writing assignments submitted by the students. In some cases, this can be augmented by observations made by staff and community partners interacting with the students. The omission of a prompt to students to reflect on active citizenship was rectified in 2010 but some students did previously deal with this theme. Many students observed that they felt a sense of responsibility to ensure they did not let anyone down. In some cases, students described being quite nervous in advance of their interaction with their community partners but said that they were proud of what they achieved and afterwards had become more confident. They also enjoyed working towards an identified common goal in a group and felt that they had a clearer idea of the type of professional role their qualification would lead to. Staff made similar observations about the students and were impressed by their commitment and the creativity many of them brought to their projects.

The variation in the extent of critical thinking and self-awareness in the reflections prepared was striking. Due to the nature of the group projects involved, there were some incidences of groups not meeting deadlines or of individual members not putting in sufficient effort. In several of the groups where significant problems arose, it was found that some students took the opportunity to think critically about them and, as a result, it was obvious that significant personal development had occurred. However, some other students chose to ignore these difficulties and neglected to discuss them, thereby losing an opportunity to learn from what had happened. It is not easy to ensure that this does not happen, particularly when students may not be comfortable with the degree of self-honesty required, but it is an area we would like to try to address. 


\subsection{Implications for adoption of community-based learning by other institutions}

The implications of the main outcomes of this case study for adoption of community-based learning in other institutions will now be examined. The findings have been grouped into two categories - potential difficulties and benefits.

\section{(i) Potential difficulties associated with adoption of community-based learning}

It is important to establish a clear understanding of what CBL is and the related aims at both a departmental and, if feasible, an institutional level before implementing this pedagogical approach. In countries such as the United States, where CBL/service-learning is welldeveloped, the terminology used is recognised widely and this facilitates clear communication to department heads, colleagues and students. However, when adopting CBL in an environment where it is not so prevalent, it is recommended that the terms used and the underlying rationale are defined and explained unambiguously from the outset. It has been noted that the successful development of the SLWC programme in DIT has resulted in a much improved awareness of CBL at an institutional level since 2006.

The induction period when the concept of $\mathrm{CBL}$ and the project or learning activity involved is presented to students is a critical time. Learners will require sufficient support and encouragement to ensure that initial fears and worries are addressed. If possible, it is helpful to incorporate an opportunity for other students who have already been involved in a CBL project or representatives of any institutional body responsible for promoting CBL to meet them. The academic staff involved as facilitators need to pay attention to any significant problems that may develop among a particular group and ensure that constructive progress is being made. A "service-learning contract" approach is used in some institutions. In Snow College, USA, this system makes it the student's responsibility to carry out research to find out what CBL is and to propose their own CBL project (Black, 2010). This approach gives students more ownership of the activity and thus helps avoid any initial apprehension or negativity.

As already discussed, CBL activities generally involve teamwork and this can lead to difficulties, particularly when some team members are perceived not to be contributing as much as the others or when agreement cannot be reached on how to achieve goals and outcomes. In the activities described in this paper, we found that allowing Year 4 students to select their own groups worked best but it was more effective to pre-assign Year 2 students to 
particular groups. It is important that the academic facilitator addresses the challenges and benefits of teamwork as well as its relevance to working in a professional environment. A recommendation that each group establishes ground rules (e.g. an agreement not to interrupt someone else when they are speaking, to remain calm and civil with each other and to only provide constructive criticism) and that they record brief minutes (action items, persons responsible and dates for completion) each time they meet formally is very useful in this regard. This issue is not unique to $\mathrm{CBL}$ and applies to any group-based learning and teaching activity (Livingstone and Lynch, 2002). An associated benefit however is that students generally recognise that their teamwork skills have improved as a result of participating in a CBL project.

The issue of an excessive time commitment being involved for CBL activities was raised by some final year students (Activity B). In this case, we reviewed the average number of hours that were required and were satisfied that they were proportional to the academic credits awarded and communicated this back to the student group. It may be that some students felt pressurised as they had not implemented effective time management. However, there is no doubt that the time commitment involved and scheduling of assessment submission dates are important considerations in ensuring that a CBL activity introduced is successful. We have found that is helpful to recommend that students only work with others who share the same college timetable. Within the same cohort, laboratory schedules may differ and, as a result, group communication and logistical considerations become more difficult.

The self-assessment (Shumer, 2000) performed identified two action areas to be addressed; encouraging meaningful student reflection and meeting genuine community needs. These are two important issues to consider when implementing CBL. Student reflection is easier to promote among learners who have already encountered critical reflection in other modules and it tends to be more of a problem in scientific and technical disciplines. It is recommended that the literature in this area is consulted (for example, Bringle and Hatcher (1997)) and that those who lack experience in facilitating and assessing critical reflection consult a peer or colleague who possesses these skills. The challenge of ensuring that genuine community needs are met is central to CBL. Therefore, an open and honest relationship with community partners as well as a clear explanation of the terms used and the underlying rationale is essential. Support at an institutional level to help find suitable community partners, 
particularly involvement in long term multidisciplinary projects as has been facilitated by the SLWC staff at DIT, is invaluable.

One other issue that has been raised by DIT academic staff is that, while involvement in CBL is a very rewarding experience, it is often the case that a significant extra time commitment is required from them, particularly during the initial implementation. It is unlikely that this problem can be solved easily although some DIT staff have obtained funding to "buy out" some of their teaching hours in order to develop CBL modules. Sustainability is therefore an important consideration and measures similar to those described in this paper (all lecturers accompany a group of students to a school once every two years for Activity $\mathrm{C}$ and students find their own community partner for Activity B) are recommended. Commitment at an institutional level is also an important factor.

\section{(ii) Benefits associated with adoption of community-based learning}

CBL activities are rewarding for the students, academic institutions, academic staff and community partners involved. The benefits have already been discussed but it is useful to summarise them here. Students gain by engaging in active learning and applying their subject knowledge in a real world context and they develop key skills (teamwork, time-management and communication) as well as improving their confidence, their sense of civic engagement and their understanding of professional roles they can enter when they qualify in their discipline. Advantages for colleges include the associated good publicity and positive community relations. Academic staff can combine community engagement with their work and are dealing with more engaged and motivated students who have a better grasp of the applications of their subject. This should also lead to improved retention. The intention of $\mathrm{CBL}$ is that the needs of the community are given equal weighting to those of the students and, thus, community partners also benefit.

\subsection{Likely obstacles and pitfalls associated with adopting a community-based learning approach to teaching and learning chemistry}

As this paper deals with the implementation of CBL in a chemistry department, the potential barriers to adopting a CBL approach that are specific to this discipline are now examined. One obstacle is that CBL is not as well-established in chemistry as in many other areas and there are not many subject-specific articles and resources. The situation is improving 
however and the prevalence of relevant articles in chemistry education journals is slowly increasing. In addition, those who are actively involved are a small but enthusiastic and supportive community. Sutheimer (2008) has recommended ways in which the adoption of CBL in chemistry departments can be simplified and her pragmatic suggestions include opting for a "simple short project (SSP)", using your own academic institution as a community partner and selecting a project in an area that is peripheral to chemistry.

Chemistry practical work often requires careful consideration of health and safety issues which can slow down development of a CBL project or activity. There are also often legal and ethical issues. For example, when an analysis is carried out by a student, a disclaimer should be provided to say that any significant results would need to be checked by a laboratory with the appropriate certification. These problems can be overcome but it is important that they are anticipated. The requirement for critical reflection by students on their CBL experience can also prove to be a significant obstacle for both staff and students if they are unfamiliar with this approach. The provision to students of prompts and questions to reflect on is recommended and academic staff may be able to seek training from academic development staff or from their CBL/service-learning support office.

\section{Summary and conclusion}

This purpose of this paper is to present a case study on the implementation since early 2007 of community-based learning (CBL) activities in a chemistry department in Ireland (the School of Chemical and Pharmaceutical Sciences at Dublin Institute of Technology). The terminology associated with student learning from community engagement at a local, national and international level and the importance of clear communication in that regard is addressed initially. A critical assessment of the implementation of $\mathrm{CBL}$ in an individual School in a third-level institution which did not have a well-established culture of applying this teaching and learning strategy at the time is then presented. The approach used from initial implementation is to identify suitable activities already in place that could be modified and to ensure that the learning outcomes and assessments are in alignment with the modified teaching and learning activities. The positive impact of the evolution of the institutional culture as a result of the activities of the CLP and its successor, the SLWC programme, is also evident from this case study (e.g. coordination of two cross disciplinary 
CBR projects, provision of training on student reflection and introduction to potential community partners).

In relation to the impact on student learning, analysis of assessment grades, reflective statements and evaluation forms allow the identification of several themes which include the value of the active learning and application of knowledge in authentic situations that takes place and the development and appreciation of key skills (communication, information literacy, teamwork) that occurs. In addition, the importance of providing an "induction" to CBL for students and an awareness of potential difficulties that can arise from time management and group conflict issues is identified. The role of personal development in student-community engagement is also evaluated and the critical contribution of effective reflection is recognised. One significant omission up until this year was providing an explicit prompt to students to consider civic engagement when reflecting.

The self-assessment (Shumer, 2000) undertaken identifies current strengths ("We consider SLWC activities important in improving teaching and learning", "The purposes of our SLWC programme are clear to everyone involved" and "The purpose of our initiative is clearly linked to meaningful activities and learning objectives"). In addition, priority areas for action have been established. These are the level of student reflection that occurs and confirmation that genuine community needs are being met.

Implications for the adoption of CBL by other institutions are then drawn together and potential difficulties and benefits are discussed. Specific obstacles that may be encountered when implementing a CBL approach to teaching and learning chemistry are also addressed and the main concerns are that it is difficult to find many examples of chemistry CBL projects, subject-associated health and safety and legal considerations and a lack of familiarity among staff and students with the type of critical reflection required. This paper also allows dissemination of some innovative practices as $C B L$ is not well-established in the discipline concerned, chemistry, and it has also not often been applied to the benefit of small local businesses. 


\section{References}

Ahern, N. (2005) Speech at opening of the Dublin Institute of Technology's Community Learning Programme, available at: http://www.pobail.ie/en/MinistersSpeeches/2005/June/htmltext,6385,en.html (accessed 16 January 2010)

Biggs, J. (1999), "What the student does: Teaching for enhanced learning", Higher Education Research and Development, Vol. 18 No. 1, pp. 57-75.

Biggs, J. (2005), "Aligning teaching for constructing learning", Higher Education Academy Discussion Paper, available at: http://www.heacademy.ac.uk/assets/fbiggsYork/documents/resources/resourced atabase/id477 aligning teaching for constructing learning.pdf (accessed 18 January 2010).

Black, D. (2010), "Service learning contracts for improved "real" service", paper presented at the Biennial Conference on Chemical Education (BCCE), 1-5 August, University of North Texas, United States, abstract available at:

http://www.bcce2010.org/program_schedule/TuesdayMorningProgram.pdf (accessed 20 August 2010).

Bringle, R.G. and Hatcher, J.A. (1996), "Implementing service learning in higher education", Journal of Higher Education, Vol. 67 No. 2, pp. 221-239.

Bringle, R.G. and Hatcher, J.A. (1997), "Reflection: Bridging the gap between service and learning", College Teaching, Vol. 45 No. 4, pp.153-158.

Boland, J.A. and McIlrath, L. (2007), "The process of localising pedagogies for civic engagement in Ireland: the significance of conceptions, culture and context", in McIlrath, L. and Mac Labhrain, I. (Ed.), Higher Education and Civic Engagement: International Perspectives, Ashgate, Hampshire, UK.

Cooke, T. (2009), "Submission by the DIT Community Links Programme to the Higher Education Authority National Strategy for Higher Education", available at;

http://www.hea.ie/files/files/file/DoE/Cooke,\%20T\%20Prof,\%20DIT\%20Community\%20Lin ks\%20\%2014.pdf (accessed 10 January 2010).

Draper, A.J. (2004), "Integrating project-based service-learning into an advanced environmental chemistry course", Journal of Chemical Education, Vol. 81 No. 2, pp. 221-224.

Esson, J.M., Stevens-Truss R. and Thomas A. (2005), "Service-learning in introductory chemistry: Supplementing chemistry curriculum in elementary schools", Journal of Chemical Education, Vol. 82 No. 8, pp. 1168-1173.

Hatcher-Skeers, M.E. and Aragon, E.P. (2002), Combining active learning with service learning: A student-driven demonstration project", Journal of Chemical Education, Vol. 79 No. 4, pp. 462-464. 
Kerins, A. (2010), An Adventure in Service-Learning: Developing Knowledge, Values \& Responsibility, Gower, UK.

Kesner, L. and Eyring, E. M. (1999), “Service-learning general chemistry: lead paint analyses", Journal of Chemical Education, Vol. 76 No. 7, pp. 920-923.

Livingstone, D. and Lynch, K. (2002) "Group project work and student-centred active learning: two different experiences", Journal of Geography in Higher Education, Vol. 26, No. 2, pp. 217-237.

Middlecamp, C., Jordan, T., Schlacter, A., Lottridge, S. and Oates, K. (2006), "Chemistry, society and civic engagement, part I: the SENCER project", Journal of Chemical Education, Vol. 83 No.9, pp. 1301-1307.

Mulder, H. (2008), "Science shops and student research: Dutch experiences", paper presented at University College Cork Science Shop Conference, April 4, Cork, Ireland, presentation available at:

http://www.ucc.ie/en/scishop/prog/DocumentFile,53167,en.pdf (accessed 29 January 2010).

Royal Society of Chemistry (2010), "Chemistry at Work, A Handbook for Organisers", available at: http://www.rsc.org/images/Handbook2010_tcm18-173636.pdf (accessed 28 January 2010).

Shoemaker, L. (2006), "The Application of Learning Skills in an Engineering Programme". Level 3, Issue 4, online publication, available at:

http://level3.dit.ie/html/issue4/leslie_shoemaker/shoemaker_1.htm (accessed 16 January 2010).

Shumer, R. (2000), "Shumer's Self assessment for service learning", available at: http://servicelearning.org/instant_info/links_collection/index.php?popup_id=136 (accessed 14 September 2009).

Simola, S. (2009), "A service-learning initiative within a community-based small business", Education + Training, Vol. 51 No. 7, pp. 567-586.

Sutheimer, S. (2008), "Strategies to Simplify Service-Learning Efforts in Chemistry", Journal of Chemical Education, Vol. 85 No. 2, pp. 231-233.

Thompson, M., Oakes, W. and Bodner, G. (2005), “A Qualitative Investigation of a FirstYear Engineering Service-Learning Program”, Proceedings of the 2005 American Society for Engineering Education Annual Conference \& Exposition available at: http://soa.asee.org/paper/conference/paper-view.cfm?id=21679 (accessed 16 June 2010)

Wiegand, D. and Strait, M. (2000), "What is service learning?", Journal of Chemical Education, Vol. 77 No. 12, pp. 1538-1539. 
Wynne-Jones, G., (2009) "Dig in with the neighbours", Irish Times, 18 March, available at: http://www.irishtimes.com/newspaper/features/2009/0318/1224242994067.html (accessed 10 January 2010)

\section{Notes}

I. DIT SLWC main webpage, available at:

http://www.communitylinks.ie/community-learning-programme/ (accessed 10 January 2010).

II. DIT webpage with report on first Chemistry at Work event, March 2007, available at: http://dit.ie/colleges/collegeofsciencesandhealth/chemistry/noticeboard/chemistryatworkdit20 08/firstrscchemistryatworkeventintherepublic/ (accessed 10 January 2010).

III. DIT webpage with report on CBL initiative with local secondary school, available at: http://dit.ie/colleges/collegeofsciencesandhealth/chemistry/noticeboard/chemistryintheco mmunity/chemistryinthecommunity/\#d.en.21719 (accessed 10 January 2010).

IV. DIT SLWC webpage with report on CARS project, available at: http://www.communitylinks.ie/slwc/projects/college-awareness-of-road-safety-cars/ (accessed 28 September 2009).

V. DIT SLWC webpage with report on LIFELINE and community gardening project, available at: http://www.communitylinks.ie/slwc/projects/grangegorman-community-gardening-project/ (accessed 28 January 2010). 